
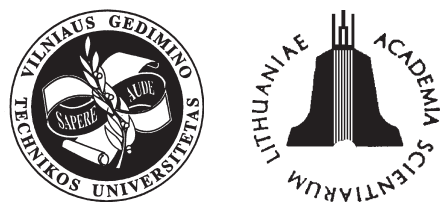

\title{
NEW AESTHETICS OF THE CITY - DESIGN OF CYCLISTS TRAFFIC SIGNS
}

\author{
Branimir Stanić, Darko Vujin \\ Faculty of Transport and Traffic Engineering, University of Belgrade, \\ Vojvode Stepe 305, 11000 Belgrade, Serbia and Montenegro, \\ E-mail:d.vujin@sf.bg.ac.yu
}

Received 30 June 2005; accepted 30 September 2005

\begin{abstract}
In a number of towns and cities worldwide development programmes have been initiated to provide designated bike surfaces reserved for the movement of cyclists along city network. There has been an increase in the use of a bicycle as a regular means of personal transport, particularly in recent years when technical solutions and modern materials have allowed more active use of bicycles in big cities. Judging from the perspective of bicycles, Belgrade has undergone several significant changes. In the period preceding the Second World War the number of bicycles in the city (area of which used to be much smaller than today) was considerable, particularly in relation to vehicles. In the following periods, the development of the city has gradually pushed bicycles towards outskirts. Today bicycles are mostly used for recreation purposes. In this process special signalization addressed to cyclists has been mainly neglected. So-called standard info-solutions, essentially addressed to drivers, were applied. New aesthetics of the city, as one of possible ideas of the urban space re-engineering, is based also on the introduction of „Zones $20 ” 20 \mathrm{mph}(30 \mathrm{~km} / \mathrm{h})$ zones as well as on more active use of bicycles. In addition, both mentioned measures increase ecological quality of life in the city. A new concept of info-system addressed to cyclists moving in a street network of a big city (Case Study of Belgrade, 2004) is presented in this paper.
\end{abstract}

Keywords: bicycle corridors, bicycle info-concept, diamond-shaped bicycle signs, sustainable urban travel.

\section{Basic data and facts}

Prior to the Second World War, legal regulation related to roads, traffic and built-up areas, i.e. towns and cities of the Kingdom of Serbs, Croats and Slovenes (the Kingdom of SHS) and later on to the Kingdom of Yugoslavia, mainly was created in the period from 1937 to 1940 , although there were individual local ordinances related to traffic regulation in towns and cities (the Danube Province, Belgrade 1907, Sombor 1930, Čačak 1931, etc). For example, for the Danube Province, inter alias, according to effective rules it was obligatory for bicycles ("velocipedes") to be equipped with white front lights for riding during nights, etc. In "The Ordinance on Protection of Public Roads and Traffic Safety on Public Roads (1929, in Serbian)" cyclists were mentioned for the first time as road users being in conflict with other road (and street) users due to the fact that they "really realized great travelling speeds". It is interesting that cyclists of that period, similar to other road users (coachmen, drivers of motor vehicles) had adequate permits driving licenses and, so called, vehicle licenses (bicycle registration cards). Otherwise, driving licenses in the former Kingdom of SHS were issued in Belgrade starting from sometime about the year of 1912.

At that period a bicycle existed in its relatively modern form, primarily due to the appearance of adequate pneumatics. From the technical point of view, in the road and street network of that time, there were no traffic signs in a modern sense as they look like today, and, of course, cycling regulation was exclusively on the level which describes "hazardous conduct" of bicycle riders. As an interesting significant detail it can be mentioned that "Pobeda" Moto-Cycling Club (Novi Sad, 1932) established a code of conduct for the cyclists on the basis of "cyclists' battalions" regulations, as well as the rules for cycling ball games with sticks (a game similar to hockey). Obviously the social role of the cyclists was very important because in 1933, for example, "Hajduk Veljko" AutoMoto-Cycling Club was founded in Negotin, etc.

In the 30s of the twentieth century (in 1936 to be more precise) 9332 motor vehicles ( 2170 cars), 542 motorcycles and 6,037 bicycles were registered in Belgrade. Thus, the number of bicycles exceeded the number of cars by 2,8 times, in 1937 by 3,6 and in 1938 by 3,7 times (Table 1.1, Statistic Almanac, Book VIII 
Table 1.1. Number of cars and bicycles in Belgrade and Kingdom of Yugoslavia in 1937 and 1938

\begin{tabular}{|l|c|c|c|c|}
\hline \multirow{2}{*}{ Year } & \multicolumn{2}{|c|}{ No PC+TAXI } & \multicolumn{2}{c|}{ No of bicycles } \\
\cline { 2 - 5 } & Belgrade & $\begin{array}{c}\text { Kingdom of } \\
\text { Yugoslavia }\end{array}$ & Belgrade & $\begin{array}{c}\text { Kingdom of } \\
\text { Yugoslavia }\end{array}$ \\
\hline 1938 & 3089 & 13561 & 11467 & 372399 \\
\hline 1937 & 2549 & 11347 & 9180 & 279767 \\
\hline
\end{tabular}

and IX, General state statistics, Kingdom of Yugoslavia, 1937, 1938 and 1939).

The first traffic signs were introduced in Belgrade in 1936 by way of "Ordinance on Traffic Regulation (in Serbian)". These were traffic signs that regulated street parking as well as signs for one-way traffic streets, i.e., permitted movement direction. These signs were in effect for cyclists as well. These signs were in accordance with so-called Geneva Convention and it is obvious that former government regularly updated international traffic regulations. More intensive use of traffic signs in our country started in 1954 with the ratification of the well-known Convention on Road Traffic (known as Geneva Convention, 1950). At that time the first updated "Code on Traffic Signs (in Serbian)" and "Ordinance on Traffic on Public Roads (in Serbian)" were issued. Until the year 1960 in our country 40 traffic signs were in use (the term "old signs" is used to denote signs which were in effect before the Second World War as well). Among these signs there were no signs exclusively relating to cyclists. Cyclists are mentioned only in one sign: a special group of signs "No Carts, Vehicles and Bicycles (in Serbian)". In the scope of the new 60 signs (in compulsory use since 1960) two traffic signs were addressed to cyclists: a group of signs "Restrictive and Regulatory Signs": "No Cycling" and "Bicycles Only".

More than 180 (so called, standard) traffic signs are in current use today. Only two traffic signs as in the 60 s are addressed to bike riders.

Belgrade, as an urban space which was used as a base for preparation of the project of new surfaces for cycling, comprises 158 minor residential areas in the vicinity of the urban tissue. In Belgrade there are somewhat less than 1500 streets with approximate length of $2100 \mathrm{~km}$. An interesting fact is that according to the data of the year 1934 about 1300 streets were registered in Belgrade, whereas only 213 streets were registered in 1921. From the point of view of land contour Belgrade is mostly cycling friendly, particularly newly developed city zones. The highest point of the city is Voždovac - $330 \mathrm{~m}$, while the altitude of the city central zone is from 115 to $118 \mathrm{~m}$. The nearest mountainous destination is Avala with the height of $511 \mathrm{~m}$. The altitude of the very confluence of the Sava and the Danube is $68 \mathrm{~m}$, and their banks have total length of $225 \mathrm{~km}$, what is, of course, very cycling friendly. Moderate continental climate prevails in Belgrade and an extremely unfavourable period for cyclist lasts between 30 and 44 days a year (snow, glaze, wind, low temperature). There are 140 days with precipitation per year. These conditions indicate that the city of Belgrade - considering its climate - is mostly cycling friendly, excluding, of course, so called "frosty" days during winter periods.

According to the present estimates about 200000 households in Belgrade (about $60 \%$ related to the total number of households) own at least one bicycle per household. Total length of the bicycle paths at present is ca $35 \mathrm{~km}$ (about 1,6\% related to the total street length). In the following next years it is planned to make about 160 to $180 \mathrm{~km}$ of bicycle paths and bicycle lanes (ca $60 \mathrm{~km}$ in the first phase) with the investment amounting to some 10,5 million euros. Such undertaking implies, among other issues, a new aesthetics of the city, as well as new look of the street scene. Besides, the creation of more than $20 \mathrm{mph}$ $(30 \mathrm{~km} / \mathrm{h})$ zones around schools and residential areas implies re-engineering of urban blocks and different organization of the traffic in the city.

Analysing the Master Plan of the City of Belgrade (in further text: MP Bgd) for the year 1972 [1], modest participation of the cyclists was recorded $(0,33 \%$ out of the total city movement, including motorcyclists). However, the Master Plan itself did not take this mode of transport into consideration. The first indication of the idea of bicycle path network in Belgrade dates to the year 1976 [2]. Namely, a concept of possible corridors for Belgrade was presented. Possible corridors along the Sava and the Danube Rivers were proposed (at that time Ada Ciganlija still was a river island) with right-angled breakthrough towards the centres of New Belgrade and old Belgrade.

The first master plan containing a concept of bicycle paths in a modest form is, so called, Phased Plan of Development of Belgrade for the period 1981 to 1990 (in Serbian) [3]. In this document it was stated that bicycle traffic should be developed in recreational zones, along banks of the Sava and the Danube, as well as in the area of New Belgrade and Zemun. Bicycle paths should be made in the main pedestrian corridors. Transport routes leading to these zones should be furnished with bicycle paths and associated equipment/furniture.

Detailed elaboration of the concept of Phased Plan was made in the scope of the Plan of Bicycle Network Development in Belgrade (in Serbian) [4]. In the meantime in the year 1994, Belgrade City Plan- 
ning Agency made a project report on Study and Spatial Program Elements and Conditions for Bicycle Paths in Belgrade (in Serbian) [5].

This project report envisages that bicycle paths be managed together with the motorized traffic and pedestrian traffic, but separately from other modes of transport. It envisages also the construction of $45 \mathrm{~km}$ of new bicycle paths in Belgrade. These program elements were applied in realization of the bicycle paths made so far.

Unfortunately, even the new MP Bgd for 2021 [6] does not devote much more consideration to cyclists. In this document the development of this mode of transport is addressed in an extremely modest manner, and primarily for recreational purposes. The fact that cycling represents a mode of transportation and not a means of recreation was overlooked.

In our opinion, a bicycle in Belgrade should not represent exclusively a recreational means of transport, as indicated by the paths foreseen in MP Bgd, but it should be an equal transport subsystem.

A "pro" reason is represented by the fact that in the total movement distribution in the area of the city of Belgrade about $3 \%$ to $10 \%$ movements are foreseen to be performed by "other modes of transport" (bicycle traffic being the most important among them) - what means that there are 300000 bicycle movements per day (taking into consideration the total number of movements in the area of MP Bgd amounting to 3,5 million movements a day). This indicates that there exists disharmony between forecast and the proposed plan because the prospect of having 300000 recreational movements per day in the year 2021 in Belgrade is extremely low.

\section{Cycling flows in Belgrade}

For almost two decades systematic traffic counts have been carried out in Belgrade at dozens of intersections (Faculty of Transport and Traffic Engineering, Belgrade). But, due to the fact that these counts are mainly performed during October and November, when there is a relatively small number of cyclists in the streets of Belgrade, there are no substantial data on the development of this mode of transport.

In the year 1999, there was the first attempt to survey the cycling traffic systematically. Abrupt increase in cycling traffic in the spring of 1999 attributable to the shortage of petrol and other well known situation in our country, led to the increased interest in the study of this mode of transportation.

The Assembly of the City of Belgrade (in Serbian) and the Secretariat for Transport initiated numerous activities with the objective to increase the safety of new road users - bicycle riders. In addition to the ac- tivities related to the construction of cycling infrastructure for the first time cyclist count at a greater number of points [7] was carried out in Belgrade streets. This survey was carried out during a summer month August, a month when a more substantial number of cyclists is likely to be in the street network - on 18 points in two days: Saturday, August 7, 1999 and Tuesday, August 17, 1999, on hourly intervals in the period between the hours of $7.30 \mathrm{a}$. m. and $8.30 \mathrm{p}$. m. It should be noted that the month of August is not considered the month with maximal cycling activities. This is due to two main reasons: weather conditions (on some days temperature was nearing $40^{\circ} \mathrm{C}$ ), as well as the fact that a portion of the chief cycling population (secondary school and university students) was away from the city. Empirical data show that the months of the most intensive cycling traffic are June and September, but there are no adequate data to support this. In the course of this study it was noticed that almost at all points/streets cyclists were riding along carriageways and sidewalks. Cyclists used sidewalks for two-way traffic, in some streets even using both sidewalks. Even at places with separate bicycle paths (say, in the zone of Ušće Promenade) exclusively pedestrian designated spaces were used for cycling. In this context the following was noted: generally, in New Belgrade half of the cyclists $(49,2 \%)$ used sidewalks for their rides - in average for two count stations. In the old part of the city only every third of cyclists $(30,7 \%)$ used sidewalks. It is obvious that the sidewalk width in New Belgrade provided more opportunities for cyclists to "escape" from unsafe carriageways.

From the summed up data on cyclist count in Belgrade streets it can be concluded that:

- During weekend days 1,087 cyclists crossed the Sava River (881 over Branko Bridge, 206 over Old Bridge). On a working day there were 888 cyclists $(695+193)$;

- On the path leading from May 25 Sport \& Recreation Centre in the direction of Ada Ciganlija Recreation Centre, on Saturday, 785 cyclists were counted; while on Tuesday 851 cyclists in both directions were counted (during day);

- On another recreational path leading from the Yugoslavia Hotel towards Ušće Promenade, on Saturday, 404 cyclists were counted, on the quay 868 (doubly more). In the course of a working day, on the bicycle path (and the quay) in the direction of Ušće Promenade there were ca $28 \%$ cyclists less (994) with identical movement characteristics;

- On the bicycle path in Goce Delčev Street there were 533 cyclists a day during weekend, or 405 during working day;

- Ada Ciganlija, as the biggest recreational area in 
the city, attracts the greatest number of cyclists. The total number of cyclists visiting Ada Ciganlija Recreation Centre on daily basis is 1658 cyclists (during weekend) and 1420 cyclists on a working day;

- Individually, on the network, the greatest scope of cycling traffic, excluding bicycle paths, was noticed on Vojvoda Mišić Boulevard, near Belgrade Fair. The total number of counted cyclists per day was 733, during weekend, and 519 cyclists per day during working day (these data relate to the period preceding opening the cycling path on Ada Ciganlija Recreation Centre to traffic);

- The number of cyclists per hour per direction exceeding 100 cyclists which were noticed during certain hours, represents a number which should be seriously considered;

- The total number of cyclists at all points in the city is ca 12000 to 13000 - in average ca 800 cyclists per hour;

- The most intensive traffic occurs in the period between 06.00 p. m. and 07.00 p. m., about $15 \%$ of total all day traffic. This is important because this period is the least favourable period for cyclists from the point of view of weather conditions (dusk, reduced visibility).

This survey was repeated in 2003 on a greater number of counting points [7].

The results obtained during cyclists count and the study of traffic characteristics in the area of the city of Belgrade carried out in November 1999 and November 2003 [8] were compared in order to support already mentioned thesis of pronounced seasonal imbalance of cycling traffic. Table 2.1 shows the results from cyclist counts for August and November in the years 1999 and 2003, on two locations (which are comparable) in the hours from $8.00 \mathrm{a}$. m. to $7.00 \mathrm{p}$. m. The difference in the scope of cycling traffic is evident at the first sight.

Note for Table 2.1: Substantially less cycling traffic was counted in the vicinity of Belgrade Fair in 2003 because a bicycle path from 25 May Sport \& Recre-

Table 2.1. Number of bicycles in Belgrade in two comparable locations

\begin{tabular}{|c|c|c|c|c|}
\hline Location & $\begin{array}{c}\text { August } \\
1999\end{array}$ & $\begin{array}{c}\text { Nove- } \\
\text { mber } \\
1999\end{array}$ & $\begin{array}{c}\text { August } \\
2003\end{array}$ & $\begin{array}{c}\text { Nov. } \\
2003\end{array}$ \\
\hline $\begin{array}{c}\text { Belgrade Fair } \\
\text { (Vojvoda Mišić Blv) }\end{array}$ & 565 & 0 & 197 & 13 \\
\hline $\begin{array}{c}\text { New Belgrade } \\
\text { Municipality Bldg }\end{array}$ & 267 & 6 & 468 & 55 \\
\hline
\end{tabular}

ation Centre to Ada Ciganlija Recreation Centre was not completed in 1999, so a great number of cyclists used this very boulevard on their way to Ada Ciganlija Recreation Centre.

Regarding the movement of cyclists on carriageways and sidewalks, the following was observed: in New Belgrade almost half of the cyclist $(1999-49,2 \%, 2003-40,0 \%)$ used sidewalks, in average for two count stations, while in the old part of Belgrade more and more cyclists (1999-30,7 \%, 2003 $-43,0 \%)$ tend to use sidewalks. This increase in movement on sidewalks in the old part of Belgrade can be attributed to the growth in motorized traffic, so that the "escape" of cyclists from unsafe carriageways to sidewalks represents the only available solution.

The data obtained during these studies may be used for implementing right measures with the aim to improve the conditions of cycling traffic. In general, comparing the data from the years 1999 and 2003, the following was noted:

- Daily in the streets of Belgrade in 1999 there were from 9000 to 10000 cyclists, in average ca 900 per hour, while in 2003, there were 6000 to 7000 cyclists, in average ca 550 per hour;

- The number of cyclists who cross the Sava during one day over Branko Bridge and Old Bridge in 1999 was ca 1110 cyclists, while in 2003, the number of cyclists was reduced to ca 130 ;

- The biggest cyclist flow in 1999 was in Vojvoda Mišić Boulevard (over 700 per day);

- The most intensive traffic was recorded in the period between 6.00 p. m. and 7.00 p. m., about $15 \%$ of all day traffic, what is significant because this period is the least favourable period for the cyclists from the point of view of weather conditions (dusk, reduced visibility);

- Significant decrease in cycling traffic was recorded in Vojvoda Mišić Boulevard from 1999 to 2003, due to the fact that a bicycle path in the direction of Ada Ciganlija Recreation Centre was not opened for traffic in the period of the study, and after its opening for traffic between 1000 and 1300 cyclists appeared on this bicycle path per day;

- Studies carried out after 2003 show that there are more bikes in the streets of Belgrade on working days than on weekend days - what is not realistic. The rain caused obvious decrease in the number of cyclists per hour on Sunday afternoon during traffic count.

The decrease in the number of cyclists in the streets of Belgrade, in average by about 3000 cyclists, was perceived in the period between the years 1999 and 2003. Taking into account the fact that in the year 1999, due to extraordinary circumstances caused by 
NATO bombing - bicycles in towns and cities of Serbia were used more than ever - the data from the year 2003 are considered more realistic. Therefore, the number of cyclists that appeared in the streets of Belgrade in 1999, as well as their characteristics, can be considered a more adequate basis for future study and analysis.

Looking at the problem from the corner of realised passenger-kilometres of bicycles in transportation system (which are, naturally, very low) in relation to total number of fatalities the participants in traffic accidents (Table 2.2) the value of 82 cyclists is high. Withal, this indicator shows that the risk of cyclists should not be underestimated. The data from Table 2.3 show that all categories of cyclists according to age are taking part in traffic accidents caused by a cyclist. It is hard to estimate if the age of a cyclist has influence on those accidents because there is no data about the total number of cyclists, also about their age.

\section{New design of traffic signs for cyclists}

Bicycle ride on special paths should promote discipline and acquiring special knowledge to enable adequate behaviour in traffic. Assuming that special bicycle paths are, in a way, considered cyclists' oases, each movement along street network, particularly along streets, which are characterized by great flow of vehicles, requires a different approach from cyclists. More skilled cyclists, of course, take greater risks, but the perception of so-called objective risk in traffic is exceptionally dangerous. As it is well known cyclists are exposed to danger in almost every conflict with motorized vehicles. The degree of exposure to hazard "dangerously" increases in cases when cyclists misjudge the risk or insist on their "rights" in the course of movement along streets. If we are willing to enable a cyclist to move along streets successfully, effectively and safely there exists no other way, but strictly to separate and mark a cycling designated portion of traffic surfaces. At the same time, it is impossible to realize such an idea, if in the effective traffic regulation only two traffic signs are addressed to cyclists. Traffic studies indicate that bicycle riders (hundreds of them) are present in Belgrade street network every day, but minimum cycling facilities are at the disposal of bike riders in the street network itself.

The Project from the year 2003, i.e. 2004 [10] promotes a new concept of cyclists' signalization. The basic aim was to establish one well designed and flexible info-system different in shape from the standard traffic signs, but which is, at the same time, representing a system which graphical design in a way resembles already existing visual image created by traffic signs in use for a long time. This objective in itself is contradictory because of relatively reduced available choice of traffic signs shapes to be re-shaped.

On the other hand, it is difficult to introduce radically new traffic sign shapes due to the opposition of the police, city authorities, legislative, etc. A traffic sign shape is also influenced by production technique, due to high cost of a smaller series of traffic signs with rare non-standard shapes, etc. The number of possible shape redesigns of standard traffic signs differs from sign to sign. Traffic signs having a square or a rectangular shape provide the greatest variety of solutions, while the number of possible combinations with triangular and circular signs is relatively small. On the other hand, a rectangular shape of traffic signs is the most standard shape possible, and drivers are mainly used to numerous advertisements, billboards and other signs in the street scene, so they find it dif-

Table 2.2. Data on accidents involving persons on bicycles according to age, 2003 [9]

\begin{tabular}{|c|c|c|c|c|c|c|c|c|c|c|c|}
\hline $\begin{array}{l}\text { Participants } \\
\text { in traffic } \\
\text { accident }\end{array}$ & $\begin{array}{l}\text { Position on } \\
\text { bike }\end{array}$ & To 7 & $7-9$ & $10-14$ & $15-17$ & $18-20$ & $21-24$ & $25-44$ & $45-64$ & $\begin{array}{c}\text { From } \\
64\end{array}$ & $\Sigma$ \\
\hline \multirow{2}{*}{ Fatalities } & Cyclist & 0 & 1 & 1 & 2 & 1 & 1 & 6 & 33 & 37 & 82 \\
\hline & "Co-rider" & 0 & 0 & 0 & 0 & 1 & 0 & 1 & 0 & 0 & 2 \\
\hline \multirow{2}{*}{ Injured } & Cyclist & 22 & 79 & 160 & 109 & 87 & 62 & 323 & 456 & 336 & 1634 \\
\hline & "Co-rider" & 15 & 5 & 8 & 12 & 5 & 1 & 4 & 5 & 0 & 55 \\
\hline \multirow{2}{*}{ Casualties } & Cyclist & 22 & 80 & 161 & 111 & 88 & 63 & 329 & 489 & 373 & 1716 \\
\hline & "Co-rider" & 15 & 5 & 8 & 12 & 6 & 1 & 5 & 5 & 0 & 57 \\
\hline
\end{tabular}

Note: cyclist - person riding a bike, co-rider - person being ridden on a bike.

Table 2.3. Number of traffic accidents caused by persons on bicycles according to age, 2003 [9]

\begin{tabular}{|l|c|c|c|c|c|c|c|c|c|c}
\hline Position on bike & To 7 & $7-9$ & $10-14$ & $15-17$ & $18-20$ & $21-24$ & $25-44$ & $45-64$ & From 64 & $\Sigma$ \\
\hline Cyclist & 11 & 51 & 111 & 81 & 46 & 55 & 210 & 255 & 201 & 1021 \\
\hline "Co-rider" & 0 & 0 & 0 & 0 & 1 & 0 & 0 & 0 & 0 & 1 \\
\hline
\end{tabular}


ficult to distinguish them, even with different background colours. This problem was solved by the use of a diamond shape for the sign which is positioned in such a way that its square vertices form lines of symmetry (Fig 1).

Such design of road signs is not entirely new in our country because in the scope of standardized signage there are traffic signs III-3 (priority regulation at intersections: "Priority Road") and III-4 ("End Traffic Sign III-3"), which are positioned in exactly the same way. Similar design is used in the USA and other countries. Such solution of traffic sign design is convenient also because of rare use of these signs in our country.

In addition to the fact that traffic signs shaped in such a way differ from traffic signs which are usual in the street scene, an important issue is that they can be well combined with other traffic signs of a rectangular shape - what is of particular significance for bicycle systems (Fig 2).

Individuality has been applied to the shape of traffic signs introducing a white frame, what improves their visibility in a real surrounding. It has been proposed to have two series of traffic signs, practically with identical graphical contents, but with different background colour: traffic signs in inhabited areas, i.e., in towns and cities (white background, remainder black) and traffic signs outside of towns and cities (green background, remainder white) (Fig 3).
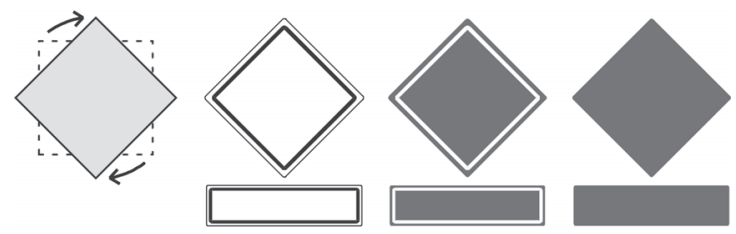

Fig 1. Diamond-shaped signs (square with one diagonal vertical)

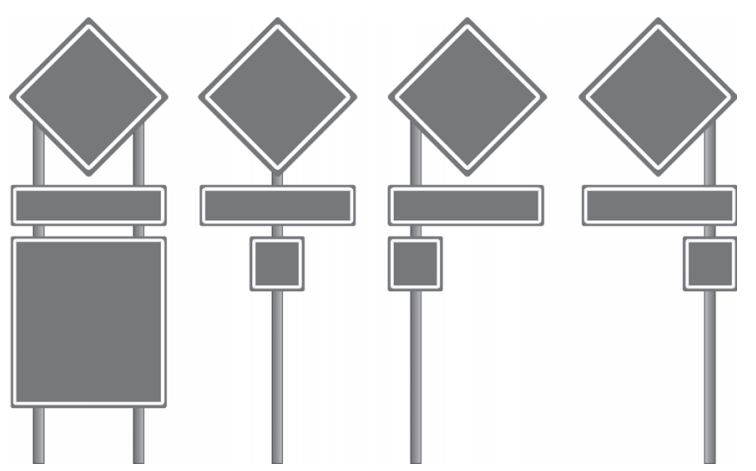

Fig 2. Combining with other traffic signs
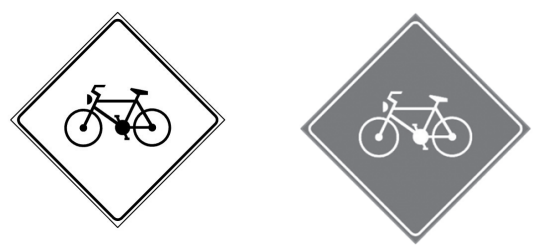

Fig 3. Signs in inhabited areas (left), and outside of towns and cities (right)

The first item from this paragraph promotes the idea of necessary discipline and certain knowledge to enable adequate behaviour of cyclists in traffic.

Figure 4 presents the draft of the info-concept, i.e. groups of traffic signs which regulate the behaviour of cyclists in the network (special traffic regimes), for various possible occurrences and situations in which they can find themselves in the course of movement (both on paths or on lanes on approaches to intersections).

In addition to these traffic signs - which are basic signs in the proposed info-concept - informative signs were also proposed designed to direct cyclists to

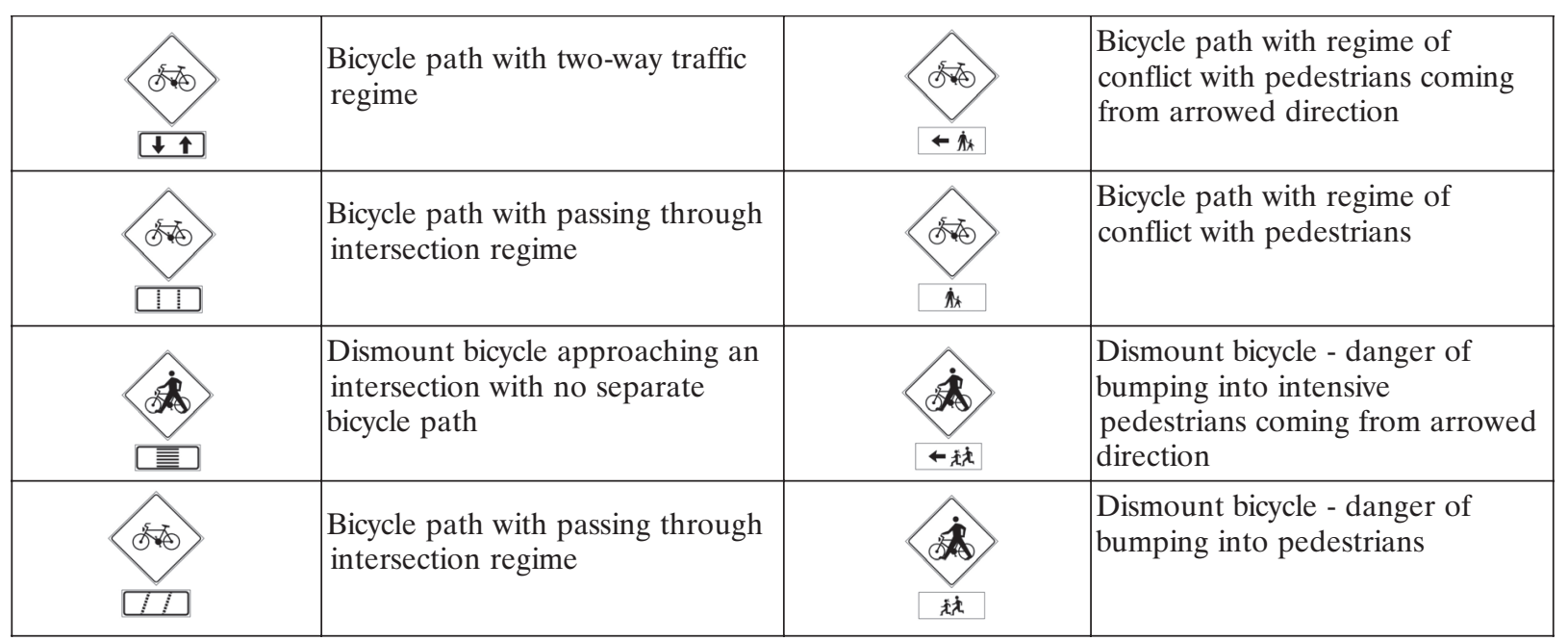

Fig 4. Groups of traffic signs for various possible occurrences and situations 
certain contents, directional signs for cyclists, markings of path numbers, etc. (Fig 5).

In total the following was proposed: 10 signs for different bicycle movement regimes in the network; 6 directional signs for city locations; and 4 directional signs for bicycle services, parking lots and special contents for bike riders. proposed traffic sign info-system for cyclists contains 20 new signs in total. The proposed info-system, in addition to new signs, contains road markings. Bicycle symbol is an international symbol. It is planned for all markings to be in white colour. Bicycle path bed - to enable maximal possible intensity of separation from other traffic surfaces - is planned to be in red colour (painted asphalt or concrete). Figure 6 shows typical solutions of road markings for various bicycle paths.

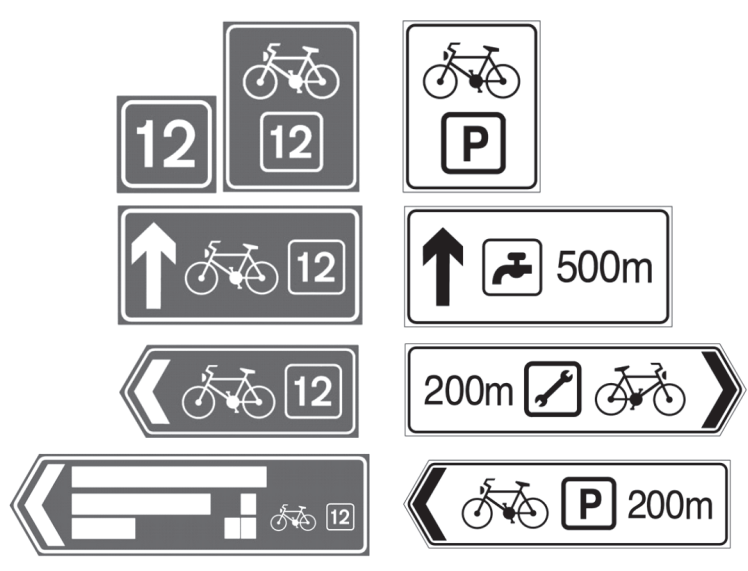

Fig 5. Directional signs for cyclists

\section{Conclusion}

The importance of national policy and institutional framework for promoting cycling is shown by the fact that based on the findings of OECD Study [11], a Declaration on National Cycling Policies for Sustainable Urban Travel was agreed by ECMT Ministers at their 2004 Ljubljana Council.

New city aesthetics, as a possible (and real) idea of urban space re-engineering, is based on the introduction of "Zones 20 " (20 mph (30 km/h) zones) and on more intensive bicycle use. Both interventions imply changes in the structure of urban blocks as well, and particularly alterations of previous approach to non-motorized traffic.

The idea of intensive introduction of cyclists into the transport of the city street network is a complex and delicate task, particularly because it is inevitable that all road users change their behaviour. We are of an opinion that such a task could be carried out with
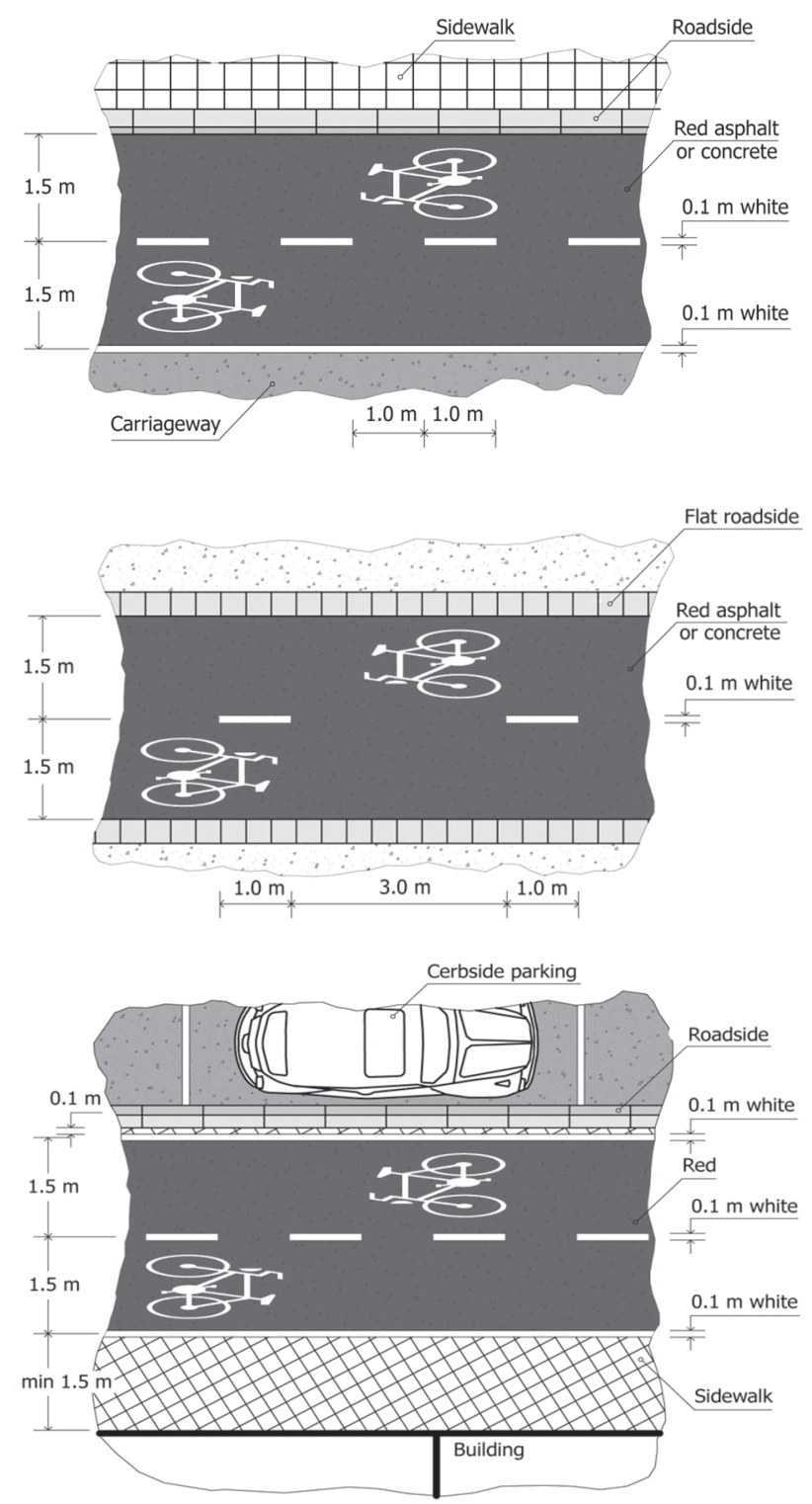

Fig 6. Typical solutions of road markings

some more radical changes in the look of the street scene, but also in info-systems which visually accentuate and support such changes. Besides, it is necessary to re-classify the road and city network and to implement $30 \mathrm{~km} / \mathrm{h}$ zones.

The proposed enlargement of the existing standard info-system of traffic signs with new signs represents a necessary action, particularly due to the fact that so far communication with cyclists has been performed exclusively in the way of various prohibitions. The basic idea of this new info-system for cyclists is the indication of positive behaviour and presentation of possible occurrences in the course of movement. Actual situations occurring in traffic were insisted upon.

Therefore, it can be concluded that the proposed info-system only indirectly insists on more radical pro- 
hibitions, i.e. these proposals tend to provide technical advice to allow safer movement. This new strategy remains still to be verified and tested under real conditions, after implementing the system of bicycle paths and lanes in the street network.

Active use of a bicycle in a big city and adequate shaped infrastructure and info-system represent one form of intervention in city aesthetics, of course, with other numerous urban and architectural designs.

\section{References}

1. Minjević, N. et al. Master plan of the City of Belgrade 1985 (Генерални урбанистички план града Београда 1985), Urban Planning Institute of Belgrade, Belgrade, 1972 (in Serbian).

2. Radovanac, M. Bicycle Traffic in Belgrade (Бициклистички саобраћај у Београду), Banja Luka: Yugoslav Symposium on Environmental Protection, 1977 (in Serbian).

3. Minjević, N. et al. Phased Plan of Development of Belgrade for the period 1981 to 1990 (Етапни план развоја Београда за период 1981-90.), City of Belgrade Development Planning Institute, Belgrade, 1981 (in Serbian).

4. Rubinjoni Z. et al. Plan of Bicycle Network Development in Belgrade (План развоја бициклистичке мреже Београда), Center for Urban Development Planning, Belgrade, 1986 (in Serbian).
5. Radovanac, M. et al. Study and Spatial Program Elements and Conditions for Bicycle Paths in Belgrade (Истраживање и просторно програмски елементи и услови за бициклистичке стазе у Београду), City of Belgrade Development Planning Institute, Belgrade, 1994 (in Serbian).

6. Macura M. et al. Master plan of the City of Belgrade (Генерални урбанистички план града Београда 2021), Urban Planning Institute of Belgrade, Belgrade, 2003 (in Serbian).

7. Radovanac, M. et al. Cycling Traffic Count (Бројање бициклистичког саобраћаја), JUGINUS, Belgrade, 1999 and 2003 (in Serbian).

8. Vukanović, S. et al. Study of Characteristics of Traffic in the Area of the City of Belgrade (Истраживање карактеристика саобраћаја на подручју Града Београда), Faculty of Transport and Traffic Engineering - Institute, Belgrade, 1999 and 2003 (in Serbian).

9. Database, Republic Statistical Office, Republic of Serbia, Belgrade, Serbia and Montenegro, 2004.

10. Stanić, B. et al. Study of Bicycle Corridors of Belgrade Book No. 2: Bicycle Paths Design, Signalization and Equipment (Студија бициклистичких коридора у Београду Свеска 2: Обликовање стаза, сигнализација и опрема), Faculty of Transport and Traffic Engineering - Institute, Belgrade, 2004 (in Serbian).

11. Implementing Sustainable Urban Travel Policies: Moving Ahead. National Policies to Promote Cycling, Organisation for Economic Co-operation and Development, Paris, 2004. 